\title{
Universiteit
}

Leiden

The Netherlands

\section{Ethnic profiling in the Netherlands? A reflection on expanding preventive powers, ethnic profiling and a changing social and political context}

Leun, J.P. van der; Woude, M.A.H. van der

\section{Citation}

Leun, J. P. van der, \& Woude, M. A. H. van der. (2011). Ethnic profiling in the Netherlands? A reflection on expanding preventive powers, ethnic profiling and a changing social and political context. Policing And Society, 21(4), 444-455. doi:10.1080/10439463.2011.610194

Version: $\quad$ Not Applicable (or Unknown)

License: $\quad$ Leiden University Non-exclusive license

Downloaded from: $\quad$ https://hdl.handle.net/1887/18080

Note: To cite this publication please use the final published version (if applicable). 


\title{
Ethnic profiling in the Netherlands? A reflection on expanding preventive powers, ethnic profiling and a changing social and political context
}

\author{
Joanne P. van der Leun* and Maartje A.H. van der Woude \\ Department of Criminal Law and Criminology, University of Leiden, Leiden, The Netherlands
}

(Received 29 April 2011; final version received 29 July 2011)

\begin{abstract}
Over the past decades the Netherlands has developed into a culture of control in which criminals and immigrants are mainly seen as 'dangerous others'. Tying in with this emergence of the culture of control is the development of a more preventive criminal justice system. By means of expanding preventive powers the criminal justice system is more and more aimed at detecting risky (groups of) persons as soon as possible. This so-called actuarial justice is accompanied by a great deal of discretionary power on the hands of those who have to enforce the law, bearing the risk that such powers may be carried out (in part) on the basis of generalisations relating to race, ethnicity, religion or nationality instead of on the basis of individual behaviour and/or objective evidence. The leading assumption in this article is that recent social, political and legal developments have increased the possibility for ethnic profiling in the Netherlands. Being a country of immigration, mostly immigrants tend to fall victim to these practices. Illustrated by the stop and search powers that have been introduced at municipal level in 2002 and in 2006 in the context of counterterrorism, the authors not only aim to provide insight into the complexity of actuarial justice in relation to ethnic profiling in the Netherlands but also aim to fuel the scientific debate on empirically researching ethnic profiling.
\end{abstract}

Keywords: cultural-security complex; ethnic profiling; stop and search; actuarial justice

\section{Introduction}

Racial and ethnic profiling have been primarily linked to characteristics of police culture in the existing, rather Anglo-American-centred, literature. The present article on the Dutch case takes a different stance by linking issues of profiling to changing social, political and legal developments. Over the past decades, the Dutch criminal justice landscape has changed. Whereas Adler (1983) indicated the Netherlands as a country not obsessed with crime, and Kommer (1994) referred to it as a 'beacon of enlightenment and tolerance' with regard to its penal climate, neither of these statements will hold anymore nowadays. Crime and fear of crime have become important spearheads of Dutch governmental policy. Despite dropping crime rates since 2002, incarceration rates are high, the penal system is sober and the public and political discourse on crime and potential 'dangerous others' is far from tolerant (Downes and Van Swaaningen 2007). Although the impact and aftermath of the

*Corresponding author. Email: j.p.vanderleun@law.leidenuniv.nl 
9/11 terrorist attacks have contributed to these changes, in fact, the attacks fertilised an already lush breeding ground. Lingering apprehensions of the Dutch multicultural society were raised, and issues of immigration, integration and the overrepresentation of non-western ethnic minorities ${ }^{1}$ in registered crime statistics were given a hitherto unknown acuteness (van der Woude 2010).

As Eijkman (2010, p. 2) also observes, the supposed relationship between ethnicity and social problems, especially crime and nuisance, has progressively become a political issue, resulting in extreme political statements including the calls for the 'deportation of convicted criminals with Moroccan nationality' and 'special stop and searches for Antillean youths in Rotterdam' (Jennissen 2009, Maasstad Pers 2010). The development of a discourse in which minority groups are increasingly seen and addressed as 'dangerous others', comparable to criminals, is part of a broader process of crimmigration - the merging of migration policy and crime control - in the Netherlands (Stumpf 2006, Van der Leun 2010).

This has put an increasing pressure on law enforcement officials to profile on the basis of race or nationality. Dutch police, for instance, carried out targeted 'stop and searches' questioning the identity of specific groups of aliens, such as West Africans, as well as extra alcohol controls for foreign drivers, especially those coming from Poland (Nationale Ombudsman 2009, KLPD 2010). Moreover, countless policy measures - and special funds have been introduced to deal specifically with crime problems and disorder amongst youngsters with an Antillean and Moroccan background, the main 'symbolic suspects' at the moment. Despite the growing complexity of the relationship between crime and ethnicity and the therewith connected pressure on law enforcement officials, until now, there has been little systematic research on ethnic profiling in the Netherlands (Van der Leun et al. 2010). The leading assumption in this article is that recent social, political and legal developments have increased the possibility for ethnic profiling in the Netherlands. As the Open Society Justice Initiative concluded in an extensive report on ethnic profiling in the European Union (OSJI 2009), ethnic profiling is not only impermissible under international law but can also contribute to feelings of polarisation and stigmatisation among those who are subjected to it. On the other hand, police and other services that are increasingly expected to work intelligence-led have much better computerised data at their disposal than in earlier times, and profiling techniques in general have become widely used. This in combination with political and public pressure to solve issues in which migrants are involved - and sometimes overrepresented almost inherently creates tensions which cannot be ignored. Theoretically, this also sheds a different light on the traditional explanations for ethnic profiling.

We will first discuss some important social and political changes that have contributed to the securitisation of Dutch society, creating a climate in which criminals and immigrants are often seen and framed as potentially 'dangerous'. Tying in with these changes, we will go into the development of a more preventive criminal justice system, particularly focusing on expanding preventive law enforcement powers. Furthermore, we will address the issue of ethnic profiling in relation to the aforementioned developments. Due to the lack of solid empirical research, we will conclude with recommendations with respect to a future research agenda. 


\section{The emergence of a Dutch culture of control}

The government paper Crime and Society (Ministry of Justice 1985) is generally taken to be the decisive point of change in Dutch criminal justice policy. Gradually a more business-like, centralised, bureaucratised and efficiency-oriented criminal justice policy was implemented with the goal to counter the rising crime rate as efficiently as possible (Rutherford 1996, pp. 60-61). Due to steeply rising crime rates combined with an increasingly 'liquid' and individualistic society (Bauman 2000, Boutellier 2004), concerns among the population grew and government officials feared for the public's the loss of confidence in the government (Roethof Commission 1984, p. 1).

Since then, criminal law was, and still is, seen as one of the most important means to counter the perceived loss of social control. The developments have clearly resulted in a more managerial conception of criminal law and the criminal justice system (Rutherford 1996, pp. 65-72). Despite widely shared criticism among academics, slowly but securely a rather Garlandian culture of control (Garland 2001) has emerged with almost predictable consequences, such as rising prison rates, a massively expansive criminal justice machinery and a firm 'law and order' discourse in order to protect the public (Pakes 2004, Van Swaaningen 2005, Downes and Van Swaaningen 2007). One of the key indices of the Dutch version of the culture of control concerns growing negative sentiments about immigration policy and immigrants, both in public and political discourse (Pakes 2004, Cavadino and Dignan 2006, Engbersen et al. 2007).

\section{The Netherlands as immigration country}

From the early 1960s on, the Netherlands can be considered a country of immigration, albeit a reluctant one. In this 'Golden Age' of the Dutch welfare state, 'guest workers' were recruited from the Mediterranean in order to fill the job surplus. Only much later when they started bringing their families over it began to dawn that many of them were going to stay. In the 1970s, almost half of the non-Dutch immigrants to the Netherlands came from Turkey, Morocco, Surinam, Netherlands Antilles and Indonesia. In the 1990s, the percentage of these five immigrant groups steadily declined. Since then, the share of immigrants from other countries increased from $30 \%$ in the early 1980 s to more than $55 \%$ in the first years of the twenty-first century (Engbersen et al. 2007). This includes a sizable asylum immigration and contemporary labour migration. The Dutch government started easing its immigration rules concerning the highly-skilled aliens in October 2004 (IND 2004). At the same time, immigration from other EU countries persists and has recently been rising, particularly since Poland, Bulgaria and Romania joined the EU respectively in 2004 and 2007 (Engbersen et al. 2011). Next to that a significant number of undocumented migrants reside in the country who are increasingly viewed through a crime control lens (Van der Leun and Ilies 2010).

\section{A changing public and political discourse on migration, integration and (fear) of crime}

For a long time the dominant policy model was based on multiculturalism. In line with the Dutch tradition of 'pillarisation', compartmentalisation along socio-political 
lines, there were special arrangements for immigrants, financed by the state (WRR 2007, p. 15). Incorporation policies aimed at 'mutual adaptation in a multicultural society with equal' (WRR 1979). Although there appeared to be consensus because migration problems were rarely openly discussed, discontent with failing integration in particular of groups with a Muslim background simmered.

The 2002 governmental elections in the Netherlands are often seen as a 'watershed' moment in the discussions surrounding immigration. Worries suddenly came to the fore in a very loud and open way. The rise in prominence on the Dutch political spectrum of Pim Fortuyn, an outspoken critic of 'multiculturalism' revealed a sense of uncertainty, insecurity and dissatisfaction among the population (Geddes 2003, p. 118). The issues are not exclusively claimed by right-wing parties and the fine-tuning of migration and integration still takes place within the present coalition. Three 'key' events strongly contributed to this development: the 9/11 attacks, Pim Fortuyn and the murder of movie maker Theo van Gogh (Engbersen et al. 2007). Pakes, who also points out these three events, speaks of a 'cultural-security complex' (2004, p. 293). The described paradigm shift in migration and integration policies is accompanied by an increased negative and often openly xenophobic 'us versus them' discourse by national and local politicians and the media (Zedner 2005, see also Namba, this issue).

\section{Researching crime and disorder}

Over the years, many studies found an over-representation of certain groups of immigrants and their offspring in official crime statistics, also when controlling for demographic and socio-economic differences (Haen Marshall 1997, Engbersen et al. 2007). At present Antilleans and second generation Moroccans stand out in a negative way (Blom et al. 2005). In the 1980s and 1990s most available studies pointed to the issue of selectivity: the fact that police data, crime registrations and data of the judicial system are inherently biased because they depend on police policies and routines and complex decision-making processes (Sampson and Lauritsen 1997). Crimes which are relatively often committed by immigrants are highly visible types of crime.

The Dutch Aliens Act and the Identification Act were explicitly designed to prevent discrimination of foreigners. According to some this aim has succeeded (Junger-Tas 1997, Boekhoorn et al. 2004), others doubt that. For instance, early studies reported that negative stereotyping of non-western immigrants is not uncommon among police officers (Bovenkerk 1991). Junger (1990) maintained that ethnic selectivity by the police often arises from the desire to optimise the 'organizational output' given limited police resources rather than from discrimination. Yet, Bowling (1990) argued that she overlooked influential filtering processes by the police which are shaped by institutional police practices and beliefs.

Junger (1989) maintained that because no study showed clear evidence of police discrimination in the Netherlands and because the country had a 'liberal tradition', ethnic bias was not a plausible explanation for group differences in crime figures. In a review study of two decades ago, Rovers also concluded that at the stage of arrest there was no ground to assume a selective approach towards individuals from a migrant background (Rovers 1999, cf. Wittebrood 2004). Since then, Dutch criminological literature usually accepts that selective law enforcement influences 
but not causes or explains ethnic differences in criminal involvement. Empirical studies on the aliens police and the immigration control task of the general police carried out in the 1990s demonstrated that the police at that time were very reluctant to stop and question allegedly illegally residing immigrants. This had to do with preventing discrimination but also with maintaining good community relations within neighbourhoods (Van der Leun 2003). At the moment it is not clear if or to what extent recent anti-immigration sentiments in the Netherlands have affected relations between immigrants and the police, which were traditionally relatively good. Moreover, legal and administrative changes and the increased availability of computerised data may also have changed the scene.

\section{Actuarial justice and the urge to pursue collective security}

Over the past two decades, fighting crime and fears has become prominent on the Dutch political agenda. The name change of the Ministry of Justice into the Ministry of Security and Justice in October 2010 by the current government is telling in that sense. It reflects the emergence of a culture of control, in which collective security and shielding society from possible security risks are seen as the most important goals. Less attention is paid to individual rights especially since the public also seems willing to accept restrictions upon their individual rights and liberties if that is what it takes (Muller et al. 2007). The answer to the perceived increase in crime and insecurity is mostly found in a more preventive criminal law, also referred to as actuarial justice (Feeley and Simon 1994, De Roos 2007, pp. 129-149). The term refers to the increasing focus on the early detection and prevention of possible crime threats and risks (Moerings 2003). By using risk assessments, by broadening criminal liability by means of criminalising behaviour in preliminary stages before a harmful act has taken place, by introducing new and harsher penalties and by introducing new potentially intrusive investigatory powers, everything is aimed at detecting and 'disarming' risky and possibly dangerous (groups of) persons as soon as possible (Feeley and Simon 1992, pp. 452, 457).

The introduction of stop and search powers at municipal level in 2002 and in 2006 in the context of counterterrorism is one of the (many) concrete manifestations of actuarial justice in the Netherlands. In the following section, we will first discuss the legal context, before reflecting on actuarial justice in relation to ethnic profiling.

\section{The legal context of stop and search powers in the Netherlands}

Many of the previously mentioned changes in the Dutch criminal justice system can somehow be related to high crime figures for violent crimes in the 1990s, and the subsequent public and political unrest. This also holds for the introduction of preventive stop and search powers in 2002. The answer was found in the possibility to perform preventive security searches amongst citizens in designated areas that were seen to be more prone to attract violence or public order problems. Before 2002, law enforcement officials could carry out searches if there was a reasonable suspicion of a criminal offense and in order to establish one's identity (art. 55b Code of Criminal Procedure). Preventive searches were limited to airports only (art. 52 lid 3 Weapons and Ammunitions Act). 
The legal basis for the 2002 expansion of preventive searches can be found in both the Municipalities Act and the Weapons and Ammunitions Act. After having consulted the municipal council and the public prosecutor, the powers to stop and search are vested in the mayor, by means of a by-law. The mayor decides which areas can be designated as 'security risk zones' in which anyone can be subjected to a 'preventive search' by police officers during a period of 12 hours. The police are empowered by the authority of the public prosecutor to search any individual as well as goods and vehicles, without having grounds for suspicion. The fact that these areas have been the stage of violent weapon-incidents in the past is sufficient to designate them as 'security risk zones' (Kamerstukken II 2000/2001, 26 865, nr. 7, pp. 2-3). Preventive searches can also be carried out as part of large scaled traffic controls, also known as 'phishing actions'. During these actions, bearing illustrious names such as 'Operation Dawn' and 'Operation Twilight', roadblocks are raised on parts of the highway in order to randomly check the cars that are present (see also Marks and Belur, this issue). Motorists are checked for their drivers-licenses, insurances, but also for outstanding fines, tax debts and residence permits. Besides all this, occupants as well as their luggage might also be subjected to preventive searching. The legal context of these actions has been disputed: questions have been raised about the legitimacy as well as the effectiveness (Salet 2009). All this has not contributed to a reserved attitude with regard to exercising stop and search powers: Over the years 2003, 2004, 2005 and 2006 both in Amsterdam and Rotterdam together, respectively, 47.409, 48.406, 29.786 and 18.005 preventive searches were carried out (COT 2007, p. 68). Over the year 2007 data are missing, but in Amsterdam 15.973 preventive searches were carried out in 2008 (COT 2009, p. 6).

\section{Stop and search in the context of counterterrorism}

Another body of law fitting within the trends described is Dutch counterterrorism legislation. Shortly after the 9/11 attacks in the United States, the then Dutch government announced a comprehensive action plan against Terrorism with the Action Plan Counter-Terrorism and Security (Kamerstukken II 2001/2002, 27 925, nr. 10). The plan contained a sizeable range of (inter)national measures for the intensification of the fight against terrorism (De Boer 2007). Besides a vast array of policy and institutional measures, a wide range of legislative measures has been taken. In this article, we will specifically focus on the Act on expanding the scope for investigating and prosecuting terrorist crimes (Kamerstukken II 2004/2005, 30 164). Under this act, the threshold triggering special investigative powers, such as observation, infiltration, undercover purchase and wire-tapping, is lowered. It is no longer required to have a reasonable suspicion of a criminal offence, mere 'indications' that a terrorist attack is being prepared are sufficient. Such indications are deemed to exist when the facts and circumstances suggest that a terrorist offense is being prepared. When there are indications of terrorist activity, the public prosecutor can give a verbal order to exercise stop and search powers during a 12 hour period in designated 'terrorist risk areas', a period which may be extended indefinitely (Art. 126zq, 126zr and 127zs Code of Criminal Procedure). Within the context of counterterrorism it is also possible for police officers to perform preventive searches without a preceding order by the public prosecutor in specific permanent security areas. Examples are: the Houses of Parliament, all airports, the 
train stations of the four major cities Amsterdam, The Hague, Rotterdam and Utrecht, the Media Park in Hilversum and the nuclear power station in Borssele (Art. 126 zq-zs Code of Criminal Procedure).

\section{Ethnic profiling as a lurking danger of expanding preventive powers}

The development of actuarial justice has resulted in an increase of discretionary powers for law enforcement officials. There is a risk that such activities may be carried out (in part) on the basis of generalisations relating to race, ethnicity, religion or nationality instead of on the basis of individual behaviour and/or objective evidence. This may be expressed directly or indirectly in the decisions of supervisory and/or investigative officials, regarding matters such as who they detain for identity checks, interrogation, security searches and sometimes arrest. Focal concerns and attribution theory in relation to sentencing research have shown that when faced with time and information restraints, judges tend to resort to a 'perceptual shorthand' to make decisions about the dangerousness and risk of recidivism of an offender (Tillyer and Hartley 2010). This shorthand is based on stereotypes and attributions linked to personal characteristics thereby providing an explanation for extralegal factors such as gender, race, ethnicity and social class being influential in sentencing outcomes (Steffensmeier et al. 1998). Recent research by Weenink (2009) supports the notion of perceptual shorthand influencing Dutch prosecutorial decision-making in juvenile justice cases. It is equally conceivable that police officers may develop similar shorthands. Especially while exercising investigative powers without the necessity of there being a reasonable suspicion or concrete indications one has to resort to something other than concrete offender-information to base one's decision on. Categorisation and stereotyping are inherent to police work (Wilson 1989, Bridges 1999, Philips and Bowling 2003, Bowling and Philips 2007, Miller 2010).

From a theoretical perspective it thus seems fair to seriously consider the possibility of ethnic profiling in relation to actuarial justice in the Netherlands, especially against the background of the development of a cultural-security complex. Ethnic profiling can be defined as 'the use by police, security, immigration or customs officials of generalizations based on race, ethnicity, religion or national origin - rather than individual behavior or objective evidence - as the basis for suspicion in directing discretionary law enforcement actions. It can also include situations where law enforcement policies and practices, although not themselves defined either wholly or in part by reference to ethnicity race, national origin or religion, nevertheless do have a disproportionate impact on such groups within the population and where this cannot otherwise be justified in terms of legitimate law enforcement objectives and outcomes' (OSJI 2009, p. 2). Although there is no explicit prohibition of ethnic profiling in Dutch legislation or regulations, it is a form of direct discrimination and therefore in defiance of the right to equal treatment and the ban on discrimination as included in the first article of the Dutch Constitution as well as in several international treaties that are directly applicable in the Netherlands (Eijkman 2010).

In recent years a couple of reports showed that the risk of ethnic profiling is not just a theoretical 'threat' for the Netherlands anymore: From the 2009 European Union Minorities and Discrimination Survey (EU-MIDIS) it appeared that 25\% of Dutch Muslims of Turkish origin interviewed had been stopped by the police at least 
once in 12 months prior to the survey and that of these individuals $25 \%$ had the impression that the stop was based on ethnicity. The corresponding figures for Dutch Muslims of North African origin were 26\% and 39\%, respectively (EU-FRA 2009, pp. 13-14). A 2010 survey by EU-MIDIS shows that in the Netherlands both NorthAfrican (66\%), Turkish (61\%) and Surinamese (67\%) respondents feel that discrimination based on ethnicity is very or fairly widespread. Comparable figures for autochthonous 'white' Dutch people are unavailable. Yet, the outcomes match the results of the Special Eurobarometer 296 in which a similar question was asked: for the Netherlands $79 \%$ of the respondents were of the opinion that discrimination based on ethnicity is very or fairly widespread (EU-MIDIS-5: EU-FRA 2010). After persistent complaints of minority and migrant groups in European countries about their treatment by the police and other criminal justice partners, the Open Society Justice Initiative made an inventory of police stereotyping in the Netherlands, France, Germany, Italy and other EU-states. According to this report, ethnic profiling is not only exercised on a large scale within continental Europe (OSJI 2009). The European Commission against Racism and Intolerance is also highly critical towards the situation in the Netherlands. The Commission expresses its worries about the increase of ethnic profiling in relation to preventing and fighting terrorism but also gives a more general warning about the changed tone in political and public discourse regarding minorities (ECRI 2008).

\section{Stop and search and ethnic profiling}

During the drafting of the stop and search powers outside the context of counterterrorism, the danger of a selective use of these powers was occasionally addressed, but overall not highly disputed in parliament. Most critics of the bill were reassured by the legislator who referred to the professionalism of law enforcers and the randomness of checks. In practice, it turns out that law officials tend to pick their subjects mostly based on their own intuition and experience. Clear indications or objective criteria are difficult to deduce. During the parliamentary procedure of the counterterrorism legislation, the danger of selectively applying investigative powers and therewith contributing to feelings of stigmatisation among the targeted (minority) groups, possibly even fuelling processes of radicalisation, was pointed out (van der Woude 2009). However, the standard response by the Minister of Justice would be that 'it wouldn't come to a misuse or a prejudiced use of discretionary powers'. Unsurprisingly, this was also his response to the parliamentary debates about the counterterrorist stop and search powers as well as to the highly critical report of the Dutch Council of State in which the Council explicitly warned about the danger of religious and ethnic profiling of Muslims in the aftermath of 9/11 and Madrid (Kamerstukken II 2005-2006, 30 164, nr. 5, p. 6; nr. 7, p. 21-22). Although the Minister was of the opinion that the professional and objective expert opinion of law enforcement officials should be trusted, he also stated that is not unthinkable that skin colour and traditional (religious) attire can play a certain role in this selection (Kamerstukken II 2005/2006, 30 164, nr. 7, p. 23). Despite the explicit recommendation of the Suyver Committee in 2009, which had examined the necessity of an integral evaluation of the Dutch counterterrorism legislation, to evaluate the powers' (un)foreseen negative side effects such as, for instance, ethnic profiling, this topic remains unexamined still (van der Woude 2011). 
Obviously there are several more specific powers as exercised by police officers or by other law enforcement officials, which may have repercussions in the area of ethnic profiling. Cases in point are identification checks and immigration controls. Expanded powers in these areas may very well affect the position of (alleged) irregular migrants. For instance, the most recent Aliens Act 2000, which came into force in 2001, includes several renewed and expanded provisions (artt. 50 and 53) for immigration authorities to carry out house searches for irregular migrants and also broadened the scope for stopping people in the street to ask for their identity and nationality. An independent evaluation in 2004 of the use of these powers under the renewed Aliens Act 2000 showed that the new powers were increasingly being used, which was indicated by rising numbers of immigrants being stopped and questioned (Boekhoorn et al. 2004). In addition, the amendment of the Identification Act by the Extended Identification Act on 1 January 2005 (Wet op de Uitgebreide Identificatieplicht) made it obligatory for every person over the age of 14 years to carry identification, whereas before this would hold only in specific situations.

\section{Discussion: much research ground to be covered}

The assumption that recent social, political and legal developments have increased the possibility for ethnic profiling in the Netherlands is strongly supported in the literature, policies and legislative changes reviewed above. A complex mix of background factors neatly fitting within the wider cultural-security complex is causing this changing opportunity structure for ethnic profiling. Yet, it should be realised that changing data infrastructures and emphasis on the need to use them (through, for instance, intelligence-led policing) have also contributed to these developments. In the existing Anglo-American literature, which is strongly focused on police culture and institutional racism, this aspect has received little attention.

With respect to research, we must conclude that sound and actual empirical research of the practice and effects of ethnic profiling is lacking, which is in stark contrast to the amount of research on the over-representation of migrants in registered crime and disorder. For a long time the selectivity discussion in the Netherlands was seen as old-fashioned. Researchers adopted a pragmatic stance, assuming that ethnic profiling or biased policing was not taking place. Still today, registered data are not readily available. Unlike in the UK there are no stop and search forms, and the police is not held accountable for their decisions as long as no complaints are filed.

Future research must find a way around the major problem that it is not clear what the baseline - normal treatment should be (Reitzel and Piquero 2006). With quantitative research, researchers may be able to show a disparity along ethnic lines, concluding that this is necessarily ethnic profiling is less clear-cut. Qualitative research, on the other hand, may unravel rationales behind police decisions. Therefore, a mixed approach appears to be most promising.

With respects to citizens' perceptions of police and police stops, we also have very little reliable studies, despite it being an important area of inquiry. If minority groups believe that they are treated differently, this may hugely impact on trust in the police and even backfire directly on police work.

A third type of research which is largely lacking are studies on the view of the police with respect to profiling. Rather than assuming that police officers are 
generally inclined to distrust ethnic minorities, which has been dominant in the existing literature, this would require more research including observations and interviews. In the present article we have put emphasis on the police, but it can be argued that the questions we have dealt with are just as relevant for other controlling agents, for instance, those working at borders or in private companies.

\section{Note}

1. Common terms in Dutch policy circles apart from 'non-western allochtonous' are 'ethnic minorities' or 'migrants', terms often referring to policy categories rather than to ethnic groups. The term race is hardly ever used.

\section{References}

Adler, F., 1983. Nations not obsessed with crime. Littleton, CO: F.B. Rothman.

Bauman, Z., 2000. Liquid modernity. Cambridge: Polity Press.

Blom, M., et al., 2005. Verdacht van criminaliteit. Allochtonen en autochtonen nader bekeken [Suspected of crime. A closer look at persons of foreign and Dutch heritage]. Den Haag: WODC.

Boekhoorn, P., Speller, T., and Kruijssen, F., 2004. Evaluatie Vreemdelingenwet 2000, Operationeel vreemdelingentoezicht door de politie [Operational surveillance of foreign nationals. Evaluation of the powers of the police for the surveillance of foreign nationals in the Aliens Act 2000]. Den Haag: WODC.

Boutellier, H., 2004. The safety utopia: contemporary discontent and desire as to crime and punishment. Dordrecht: Kluwer Academic.

Bovenkerk, F., 1991. Het vraagstuk van de criminaliteit der Marokkaanse jongens. De Gids, 150 (12), 8-28.

Bowling, B., 1990. Conceptual and methodological problems in measuring 'race' differences in delinquency, a response to Marianne Junger. British Journal of Criminology, 30 (4), 483-492.

Bowling, B. and Philips, C., 2007. Disproportionate and discriminatory: reviewing the evidence on police stop and search. Modern Law Review, 70 (6), 936-961.

Bridges, L., 1999. The Lawrence inquiry - Incompetence, corruption, and institutional racism. Journal of Law and Society, 26 (3), 298-322.

Cavadino, M. and Dignan, J., 2006. Penal systems: a comparative approach. London: Sage Publications.

COT, 2007. Preventief Fouilleren in Rotterdam. Maatschappelijk draagvlak, opbrengsten en effecten [Preventative searches in Rotterdam. Societal support and effectivity]. Den Haag Rotterdam: COT Instituut voor Veiligheid en Crisismanagement.

COT, 2009. Preventief Fouilleren in Amsterdam. De balans van 2008 [Preventative searches in Amsterdam. Results of 2008]. Den Haag - Amsterdam: COT Instituut voor Veiligheid en Crisismanagement.

De Boer, M., 2007. Wake-up call for the Lowlands: Dutch counterterrorism from a comparative perspective. Cambridge Review of International Affairs, 20 (2), 285-302.

De Roos, T.A., 2007. Doelbewust strafrecht en makkbare veiligheid. In: M. de Keizer and S.C. Roels, eds. Staat van Veiligheid. Zutphen: Walburg Press, 129-149.

Downes, D. and van Swaaningen, R., 2007. The Road to Dystopia: changes in the penal climate in the Netherlands. In: M. Tonry and C. Bijleveld, eds. Crime and justice in the Netherlands. Chicago: Chicago University Press, 31-72.

Eijkman, Q., 2010. Has the genie been let out of the bottle? Ethnic profiling in the Netherlands. The Journal of Law and Social Justice, 5 (2), 1-21.

Engbersen, G., et al., 2011. Destination Netherlands the evolution of migration from six origin countries to the Netherlands. Rotterdam: Erasmus University.

Engbersen, G., Van der Leun, J., and De Boom, J., 2007. The fragmentation of migration and crime in the Netherlands. In: M. Tonry and C. Bijleveld, eds. Crime and justice in the Netherlands. Chicago: University of Chicago Press, 389-452. 
European Union Agency for Fundamental Rights (EU-FRA), 2009. European Union Minorities and Discrimination Survey. Data in Focus Report: Muslims. Brussels: EUAFR.

European Union Agency for Fundamental Rights (EU-FRA), 2010. EU-MIDIS 5 Data in Focus report: Multiple discrimination. Brussels: EUAFR.

Europese Commissie tegen Racisme en Intolerantie, 2008. Derde Rapport over Nederland. Straatsburg: Raad van Europa.

Feeley, M. and Simon, J., 1992. The new penology: notes on the emerging strategy of corrections and its implications. Criminology, 30 (4), 449-474.

Feeley, M. and Simon, J., 1994. Actuarial justice: the emerging new criminal law. In: D. Nelken, ed. The futures of criminology. London: Sage, 173-201.

Garland, D., 2001. The culture of control: crime and social order in contemporary society. Chicago: University of Chicago Press.

Geddes, A., 2003. The politics of migration and integration in Europe. London: Sage.

Haen Marshall, I., 1997. Minorities, migrants, and crime diversity and similarity across Europe and the United States. New York: Sage.

IND, 2004. Status of the policy for highly skilled migrants [online]. Available from: http://www. ind.nl/en/inbedrijf/wonenenwerken/standvanzakenkennismigranten.asp [Accessed 28 April 2011].

Jennissen, R.P.W., 2009. Criminaliteit, leeftijd en etniciteit: Over de afwijkende leeftijdsspecifieke criminaliteitscijfers van in Nederland verblijvende Marokkanen en Antillianen. The Hague: Boom Legal.

Junger, M., 1989. Discrepancies between police and self-report data for Dutch racial minorities. British Journal of Criminology, 20 (3), 273-284.

Junger, M., 1990. Delinquency and ethnicity an investigation on social factors relating to delinquency among Moroccan, Turkish, Surinamese and Dutch boys. Deventer/Boston: Kluwer.

Junger-Tas, J., 1997. Ethnic minorities and criminal justice in the Netherlands. In: M. Tonry, ed. Ethnicity, crime and immigration. Comparative and cross-national perspectives. Chicago and London: University of Chicago Press, 257-310.

Kamerstukken II, 2001/2002. http://www.rijksoverheid.nl/documenten-en-publicaties/kamers tukken [Accessed 28 April 2011].

KLPD, 2010. Gerichte Alcohol Controles [Targeted alcohol checks] [online]. Available from: http://www.politie.nl/klpd/nieuws/100820gerichtealcoholcontroles.asp [Accessed 20 August 2010].

Kommer, M., 1994. Het Nederlands Strafklimaat in Internationaal Perspectief. In: M. Moerings, ed. Hoe punitief is Nederland? Arnhem: Gouda Quint, 313-330.

Maasstad Pers, 2010. Lapt Leefbaar Rotterdam de rechtsstaat aan de laars? Maasstad Pers, 1 Sep.

Miller, J., 2010. Stop and search in England. A reformed tactic or business as usual? British Journal of Criminology, 50, 954-974.

Ministerie van Justitie, 1985. Samenleving en Criminaliteit. Een beleidsplan voor de komende jaren. Den Haag: Staatsuitgeverij.

Moerings, M., 2003. Straffen met het oog op veiligheid, een onderneming vol risico's. Leiden: Leiden Law School (inaugural lecture).

Muller, E.R., Kummeling, H.R.B.M., and Bron, R.P., 2007. Veiligheid en Privacy. The Hague: Boom Legal.

Nationale Ombudsman, 2009. Onderzoek inval vreemdelingenpolitie in Amsterdams café. The Hague: Nationale Ombudsman, Report 2009-170.

Open Society Justice Initiative, 2009. Ethnic profiling in the European Union: pervasive, ineffective and disciriminatory. New York: Open Society Institute.

Pakes, F., 2004. The politics of discontent: The emergence of a new criminal justice discourse in the Netherlands. Howard Journal of Criminal Justice, 43 (3), 284-298.

Philips, C. and Bowling, B., 2003. Racism, ethnicity and criminology. Developing minority perspectives. British Journal of Criminology, 43 (2), 269-290.

Reitzel, J. and Piquero, A.R., 2006. Does it exist? Studying citizens' attitudes of racial profiling. Police Quarterly, 9 (2), 161-183. 
Roethof Commission, 1984. Interim-rapport Commissie Kleine Criminaliteit. Den Haag: Staatsuitgeverij.

Rovers, B., 1999. Klassenjustitie. Overzicht van onderzoek naar selectiviteit in de Nederlandse strafrechtsketen. Rotterdam: Erasmus University.

Rutherford, A., 1996. Transforming ciminal policy. Winchester: Waterside Press.

Salet, R., 2009. Preventief fouilleren als praktijk. Nederlands Juristenblad, 84 (27), 1724-1728.

Sampson, R.J. and Lauritsen, J.L., 1997. Racial and ethnic disparities in crime and criminal justice in the United States. In: M. Tonry, ed. Ethnicity, crime, and immigration: comparative and cross-national perspectives. Chicago: University of Chicago Press, 311-374.

Steffensmeier, D.J., Ulmer, J.T., and Kramer, J.H., 1998. The interaction of race, gender, and age in criminal sentencing: the punishment cost of being young, Black, and male. Criminology, 36 (4), 763-797.

Stumpf, J., 2006. The crimmigration crisis: immigrants, crime, and sovereign power. American University Law Review, 56 (2), 368-419.

Tillyer, R. and Hartley, R.D., 2010. Driving racial profiling research forward: learning lessons from sentencing research. Journal of Criminal Justice, 38 (4), 657-665.

Van der Leun, J.P., 2003. Looking for Loopholes. Processes of incorporation of illegal immigrants. Amsterdam: Amsterdam University Press.

Van der Leun, J.P., 2010. Crimmigratie. Apeldoorn/Antwerpen: Maklu (inaugural lecture).

Van der Leun, J.P. and Ilies, M., 2010. The Netherlands: assessing the irregular population in a restrictive setting. In: A. Triandafyllidou, ed. Irregular migration in Europe. Myths and realities. Farnham, Burlington: Ashgate, 187-206.

Van der Leun, J.P., et al., eds. 2010. Criminaliteit, migratie en etniciteit. Nieuwe richtingen binnen een complex en beladen onderzoeksterrein. Tijdschrift voor Criminologie, 52 (2) $107-121$.

van der Woude, M.A.H., 2009. Brede benadering terrorismebestrijding. Openbaar Bestuur, 11, $2-5$.

van der Woude, M.A.H., 2010. Wetgeving in een Veiligheidscultuur. Den Haag: Boom Juridische Uitgevers.

van der Woude, M.A.H., 2011. Is het Nederlandse antiterrorismebeleid écht zo degelijk vormgegeven? Een bespreking van recent uitgevoerd evaluatieonderzoek. PROCES, 90 (3), $125-141$.

Van Swaaningen, R., 2005. Public safety and the management of fear. Theoretical Criminology, 9 (3), 289-305.

Weenink, D., 2009. An analysis of the outcomes of Dutch prosecutorial decision making. British Journal of Criminology, 49 (2), 220-242.

Wetenschappelijke Raad voor Regeringsbeleid, 1979. Etnische minderheden. The Hague: Sdu Uitgevers.

Wetenschappelijke Raad voor Regeringsbeleid, 2007. In debat over Nederland. Amsterdam: Amsterdam University Press.

Wilson, J.Q., 1989. Bureaucracy. What government agencies do and why they do it. New York: Basic.

Wittebrood, K., 2004. Van delictmelding tot officiële aangifte - sprake van sociale ongelijkheid? Tijdschrift voor Criminologie, 46 (56), 56-71.

Zedner, L., 2005. Securing liberty in the face of terror: reflections from criminal justice. Journal of Law and Society, 32 (4), 507-533. 